\title{
Integration of Three CBI Models and WeChat Mobile Learning in Business English Teaching
}

\author{
Che Siqi ${ }^{1}$ \\ ${ }^{1}$ College of Continuing Studies, Guangdong University of Foreign Studies, Guangzhou, China \\ Correspondence: Che Siqi, College of Continuing Studies, Guangdong University of Foreign Studies, \\ Guangzhou, China. Tel: 86-158-1334-6916. E-mail: 743106832@qq.com
}

Received: July 25, 2017 Accepted: August 18, 2017 Online Published: August 21, 2017

doi: 10.5539/elt.v10n9p218 URL: http://doi.org/10.5539/elt.v10n9p218

\begin{abstract}
Content-Based Instruction (CBI) is considered effective not only in mastering language skills, but also in acquiring the content knowledge of business subjects. WeChat, a popular communicative and interactive platform, is acknowledged as a new instrument to improve verbal teaching proficiency and obtain relevant information. The integration of three major CBI models and WeChat Mobile Learning can form three applicable phases of Business English teaching, which is an innovative but challenging teaching approach for business English teaching.
\end{abstract}

Keywords: content-based instruction, WeChat app, business English teaching

\section{Introduction}

With fast development in international economic exchange and integration, employment markets are in great need of versatile business talents who should not only have broad international trade business knowledge and theory, but also solid language skills, strong cross-cultural communication capacity and excellent humanistic quality so as to adapt to various kinds of international business activities. However, the cultivation of this kind of talents at China's universities cannot meet the need of employment markets because the current business English teaching methods and materials are mainly language oriented. A large number of business English students, hence, still face the challenge of poor business knowledge and oral communication disorder (Dai, 2014). In order to cope with the present situation, both teachers and students should follow the progress of time and change their methods of teaching and learning and adapt to a flexible and available business English teaching model.

Nowadays, WeChat becomes China's killer application and accounts for a dominant position blending into every aspect of Chinese life. It is the highly addictive app that allows subscribers to send moments, sharing daily photos, selfie, videos, and web links. Chinese users seemingly glued to it. At work, on subways and in restaurants, anywhere you can always easily network with your friends; with WeChat you can establish new relationships by just scanning the QR code. As of May 2016, WeChat active users has reached 938 million, the average age is 26 years old. 86.2\% of users are between 18-36 years old (Xu et al., 2016; Yang, Sun, \& Lee, 2016). It can be seen that WeChat is widely used for the younger generation. Hence, in order to bring new vitality to the traditional classroom teaching, significant changes have been taken place in both what to teach and how to teach by means of WeChat platform. This mobile media platform will help carry out a variety of study activities, which can bring new experience to students.

Based on the above circumstances, CBI Teaching Models begin to be applied in business English teaching through WeChat Platform. The following part will introduce CBI Teaching Models and WeChat Platform for learning.

\section{Literature Review}

In recent years, business English teaching based on different kinds of means has drawn many scholars' attention. Many researchers tried multimodal teaching of business English. Barrow, Markman and Rouse (2009) state that computer-aided instruction, compared with traditional instruction, can make students achieve scores significantly higher on algebra test. Fan and Fang (2002) demonstrate that Internet teaching is an innovative means to conduct business English teaching with the help of high-speed development of internet, which presents a new method for Business English teaching. Miyazoe and Anderson (2010) implemented a qualitative text analysis that reveals 
students' positive perception of forum, blogs and wikis in language education. Li (2016) presents that micro-course online video teaching mode has greatly reform the traditional class, breaking the barrier between traditional teaching and interactive teaching. His study approved the effectiveness of micro-course in business English teaching (Qian-chun \& Zi-xian, 2016; Savas, 2012). Liu (2016) illustrates that MOOC platform focuses on online self-regulated learning and the experiment approved that MOOC teaching model is feasible to enhance students' business English learning initiative. All of the means above depict a huge effect on interactive business English teaching, but these means are mainly language-oriented without paying attention to students' effective acquisition of professional business knowledge. With the upsurge of WeChat app, some scholars began to concentrate on WeChat mobile interactive learning research in various fields, but few have attempted to combine WeChat Mobile Learning with Content-Based Instruction (CBI) in business English teaching, which will be the focus of this current study.

\section{An Overview of CBI Teaching Models}

\subsection{Definition}

As for the basic concept of CBI teaching method, many scholars have put forward their opinions. Dupuy (2010) points out that $\mathrm{CBI}$ teaching method is an effective teaching method of combining foreign language with content. This approach can improve second language skills and academic subjects simultaneously. Long (1997) believes the language learning and subject knowledge learning should be combined completely together. In particular, subject can be regarded as a tool to teach business English. Richards and Rodgers (1986) manifest that content-based teaching is the latest teaching method, which emphasizes the content information learning. According to this method, the primary focus of teaching should transform from the teaching language itself to learn through the subject of knowledge to obtain information. That's an innovative way to stand out from the traditional language teaching methods. Brinton, Snow, and Wesche (2010) argue that CBI is the integration of language points and specific content material to successfully and effectively facilitate second language in academic background.

\subsection{Common CBI Teaching Models}

There are three major models of content based instruction language education in use at the university level: theme-based, adjunct, sheltered (Unirow, 2012). The difference among the three models will be explicitly demonstrated below.

\subsubsection{Theme-Based Language Instruction Model}

Theme-based CBI has been widely accepted and is the most popular CBI teaching model in foreign business language learning (Satilmis, Yakup, Selim, \& Aybarsha, 2015). Unlike the traditional business English classes, where the topics are selected from a textbook, theme-based courses highlights the student-centered teaching model (Satilmis et al., 2015); the course is formed by selecting interesting topics which are concerned with students' needs, requirements and interests, especially about a wide range of social heated issues. More importantly, it can allow the implementation of various kinds of language tasks and the choice of some case studies around the subject. After carefully listening to students' needs and their previous work or study experiences, teachers can select some topics that can satisfy their tastes and language proficiency. Apart from this, student-oriented classes call for students to be actively involved in every phrase, autonomously exploring knowledge. In addition, by means of choosing authentic teaching materials, it can vividly offer an insight into different fields being studied, which could make students comprehend the real world environment and involved in contextualized language environment. It is remarkable that teacher's role has been changed, but not weakened (Kiziltan \& Ersanh, 2007). The role of teacher is, presently, a coordinator and facilitator in the process of learning and integrating topics with business terms and concepts.

\subsubsection{Adjunct Language Instruction Model}

Adjunct based instruction is actually two coordinated courses. It contains both a language subject and a content course (Kiziltan \& Ersanh, 2007). In order to efficiently launch and guide oral teaching, Baecher, Farnsworth, and Ediger (2014) underlines the idea that language teachers should be familiar with the relevant knowledge of specialized courses, which is, undeniably, a challenge to language instructors. By choosing different kinds of teaching techniques to demonstrate new words and expressions, it is particularly essential for both language teachers and content teachers to build teamwork in the actual operation. The syllabus of the two courses should go through mutual consultation (Dellicarpini \& Alonso, 2014). The intention of adjunct courses is mainly to help students who lack necessary language competence to successfully communicate in business. It, hence, will be a helper to comprehend business knowledge and to improve language expression at the same time. Under this 
model, much more emphasis for learners will be on the language proficiency, students will be assigned a great number of tasks to reach teaching objectives. In addition, it could help students to elevate their self-confidence to actively express their own opinions and deliver speeches by using the corresponding knowledge points learned from the courses. It is universally known that grammar teaching is no longer the core of teaching (Bielak \& Pawlak, 2013). In this level, Adjunct CBI does not require a high level of language skills; it mainly focuses on the ability to flexibly apply language communications and the ability to express ideas in practice. Indeed, the linguistic form is not the biggest concern. The contents of teaching far overweigh the language skills.

\subsubsection{Sheltered Content Instruction Model}

Sheltered CBI is an approach requiring students to grasp subject knowledge instead of language skills through speaking, listening, writing, translating and reading training courses, which abandons single specific skill training method (Echevarria \& Short, 2010). In specific, sheltered content instruction requires teachers to adjust their teaching materials to the learners' proficiency level (Hung \& Hai, 2016). By choosing the suitable materials, combined with comprehensive training around the theme, students' language skills can be promoted and exercised. This also needs language teacher with special expertise in diverse fields, integrating speaking, listening, writing, translating and reading in every session of teaching (Davies, 2003). In this stage, language communication skill is of vital importance.

\section{WeChat Mobile Learning}

It can be clearly seen that WeChat has become one of the indispensable tools among our daily life (Shi \& Luo, 2016). With the further development of mobile learning, WeChat has become a new autonomous learning model, which is an innovative educational information model and breaks through the traditional time and space constraints (Lang, Zhang, Li, \& Sun, 2016).

\subsection{WeChat App}

As a China's leading social media platform, WeChat is a smart terminal to provide instant messaging services for free, which was launched by Tencent Holdings Limited on January 21, 2011(Yang et al., 2016). This all-in-one application is more pervasive and creeps into every aspects of daily life from transferring files, taking video calls and making transactions. Particularly new generations are fascinated with this software.

Based on a wide range of functions on WeChat, teachers can instruct students in accordance with their own aptitude.

\subsection{Advantages of WeChat in Business English Teaching}

WeChat, as a free software, is featured for its simple interface, rich functions, easy operation and low cost. Only by consuming some data, a fashionable app will be loaded on your smart phone. Generally speaking, WeChat platform is a multimodel application, which can be divided into three major functions (see Table 1).

Table 1. Educational characteristics of WeChat in Mobile Teaching

\begin{tabular}{|c|c|c|}
\hline Functions & Function Description & Educational Characteristics \\
\hline \multirow{4}{*}{$\begin{array}{l}\text { Communication } \\
\text { Function }\end{array}$} & \multirow{4}{*}{ Instant Interaction } & Asking questions and get the answer in time; \\
\hline & & Solving left-over problems in class; \\
\hline & & $\begin{array}{l}\text { Aiming at personalized differentiation learning in } \\
\text { student-oriented class; }\end{array}$ \\
\hline & & $\begin{array}{l}\text { Improving the efficiency of teaching through Fragmented } \\
\text { learning. }\end{array}$ \\
\hline \multirow{2}{*}{$\begin{array}{l}\text { Platformization } \\
\text { Function }\end{array}$} & \multirow{2}{*}{$\begin{array}{l}\text { Public and Open } \\
\text { Platform }\end{array}$} & $\begin{array}{l}\text { Sharing business knowledge and teaching materials among } \\
\text { teachers; }\end{array}$ \\
\hline & & $\begin{array}{l}\text { Sharing personal learning experience and thoughts among } \\
\text { students. }\end{array}$ \\
\hline \multirow{2}{*}{ Social Function } & Set up Discussion & Enhancing teamwork cooperation and subjective initiative; \\
\hline & Group & Encouraging students to express personal opinions. \\
\hline
\end{tabular}

(Adapted from http://www.WeChat.com/en/). 
As noted from Table 1, WeChat communication platform offers an instant interaction tool. Users can respond immediately, communicate flexibly, and achieve real-time asynchronous communication, which guarantees the timeliness of teaching. That is to say, previously, students can ask questions only when the problems are encountered in school, which could not answered in time. The timely communication advantage of WeChat can be a good solution to this problem, that is, teachers can solve the left over problems. Students can get in touch with and ask questions at anytime and anywhere, which definitely improve the efficiency of teaching and get rid of the time and space constraints (Wang et al., 2017).

Traditionally, classroom teaching is aimed at all the students, overlooking the differences among students. In an original teacher-oriented class, teachers dominant the majority of time in the class while students have few opportunities to express their own personal opinions. The use of WeChat interactive way, however, can carry out targeted teaching to meet the needs of personalized differentiation learning. Accordingly, it is an innovative second classroom interaction (Wei, 2017). Furthermore, WeChat business English teaching is a fragmented teaching.

Nowadays, with constantly severe competition, people have a fast paced itinerary and struggle to use the fragmented time to enrich themselves. Because of its own characteristics, WeChat offers a good way to refine and condense the language when you release information, pictures, videos or voices within restricted time and length. So WeChat is the embodiment of this kind of fragmented life. For students, not only can it help to save time and improve the efficiency of learning, but also quickly browse the core knowledge and fully inspire students' subjective initiative.

Moreover, WeChat presents a great platform for knowledge sharing, which stands for a great supplementary to the traditional language teaching (Lang et al., 2016). Teachers can distribute real-time business information and language learning materials, for instance, some attracting English bilingual news, cultural differences and etiquette all over the world. Likewise, students can share their learning experience and personal useful learning resources with others. It can both benefit teachers in understanding students' thoughts and assisting students to broaden their horizons.

Furthermore, WeChat discussion group could be named as a portable English Corner. Since the business English course may relate to a great number of case studies and marketing plan books and also involve some complicated process of business practice, it claims for teamwork cooperation. Through WeChat, various discussion groups can work conveniently together, actively offer advice and suggestions and strengthen their interactive learning ability. Accomplishing tasks together by different groups can give full play to students' subjective initiative and also exercise their collaborative learning ability. It is generally acknowledged that a great number of students may face the challenge that they are afraid of expressing their inner thoughts in front of others. WeChat App may simply break the barriers in oral communication and encourage students to autonomously ask queries.

\section{WeChat Pedagogical Practice on the Basis of CBI Three Models}

Based on the characteristics of the three major CBI models and the advantages of WeChat Mobile Learning, we can integrate the three CBI models and WeChat Mobile Learning method into three phases of Business English teaching, as seen in Diagram 1. 

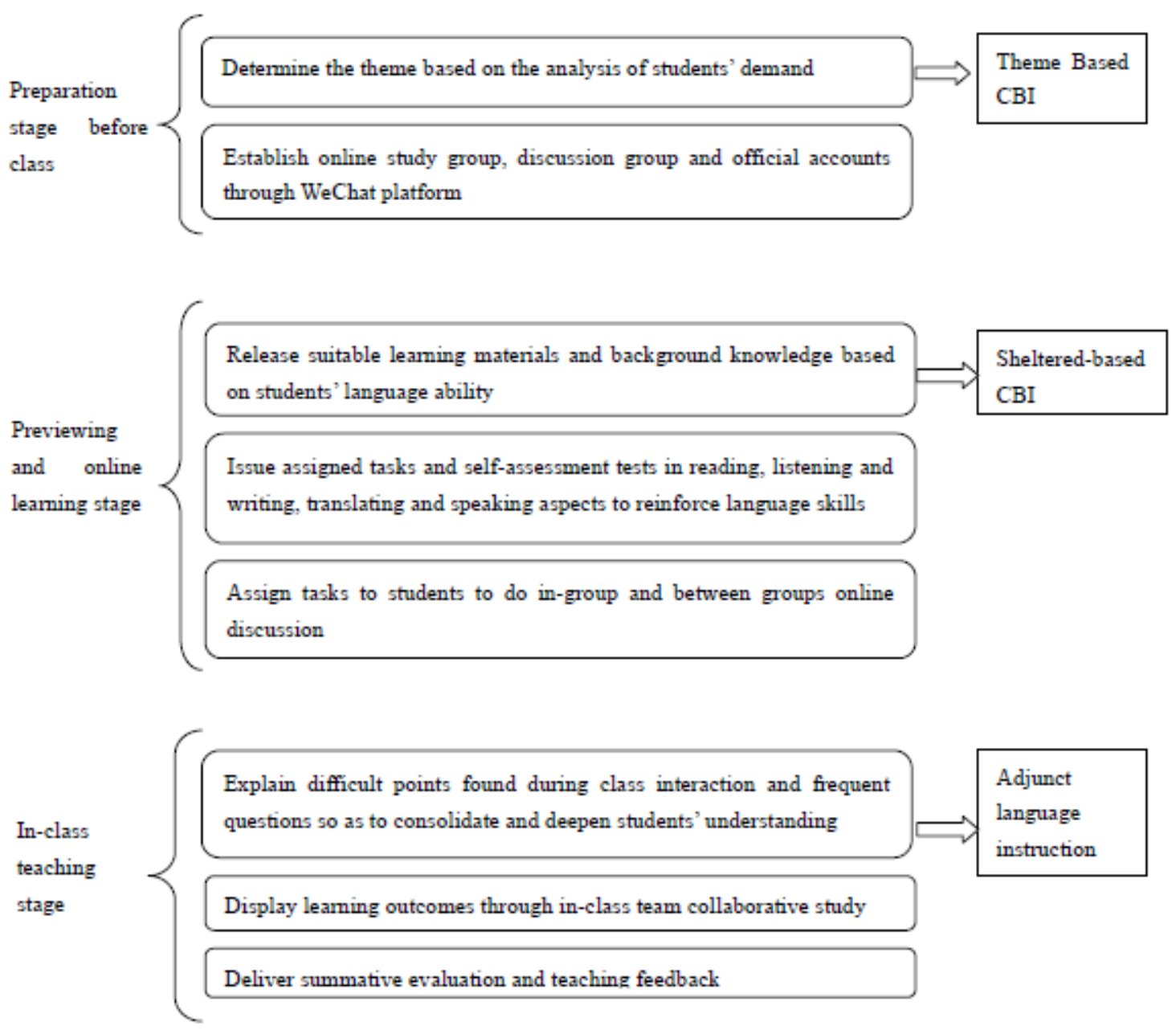

Diagram 1. Three phases of content based WeChat teaching of business English

\subsection{Preparation Stage before Class}

The first stage, "Preparation Stage before Class" is relevant to theme-based language instruction. Based on the content-based instruction theory, teachers, at the beginning, should assess students' linguistic demand through WeChat group chat. By and large, WeChat offers an interactive platform for all students to express their interests. After analyzing their requirements, instructors can upload the teaching syllabus and substantial business background knowledge by digging out some authentic reading materials prior to the class to let students be familiar with the real business environment. In other words, the teaching materials should be selected according to students' concern (Lin, 2017). Not only should the new topic draw students' attention, but also the original and natural content can arouse their interest. From the business knowledge perspective, business awareness is a tremendous barrier to those students who do not have any business or work experience (Wu, 2013). In this model, the language instructors should pay extra effort to be familiar with the business content in order to choose adequate topics for students. Equally important, online study groups and small discussion groups should be established as soon as possible. In this way, students' interpersonal relationships could be strengthened as well. All of the above are consistent with student-centered educational philosophy and

\subsection{Previewing and Online Learning Stage}

The second stage, "Previewing and Online Learning Stage" is related to sheltered content instruction. Teachers should select certain acceptable, accessible and comprehensible materials for students (Baecher et al., 2014). After confirming the content or theme, instructors may send pictures of real samples, videos, audios and related materials and describe the topic in detail or depict the key words and expressions through WeChat group, subscription accounts or moments. Instructors should choose reasonably difficult tasks for learners according to course requirements and their personal ability. Otherwise, students would feel frustrated in understanding the 
content, which would crack down the learners' interests.

The input should be accessible and certain reliable official accounts in WeChat may be highly recommended. By subscribing relevant business knowledge accounts, students can conveniently acquire information about what potential risks may exist in business, what kind of professional quality they need to have as a clerk engaged in a foreign trade business, what problems they should pay attention to when accessing to foreign trade in practice, etc.

When doing the business English language previewing, students may improve their own listening, speaking, reading, writing and translating skills through WeChat. Diagram 2 below reveals how student-centered diverse language skills assist business content learning through WeChat.

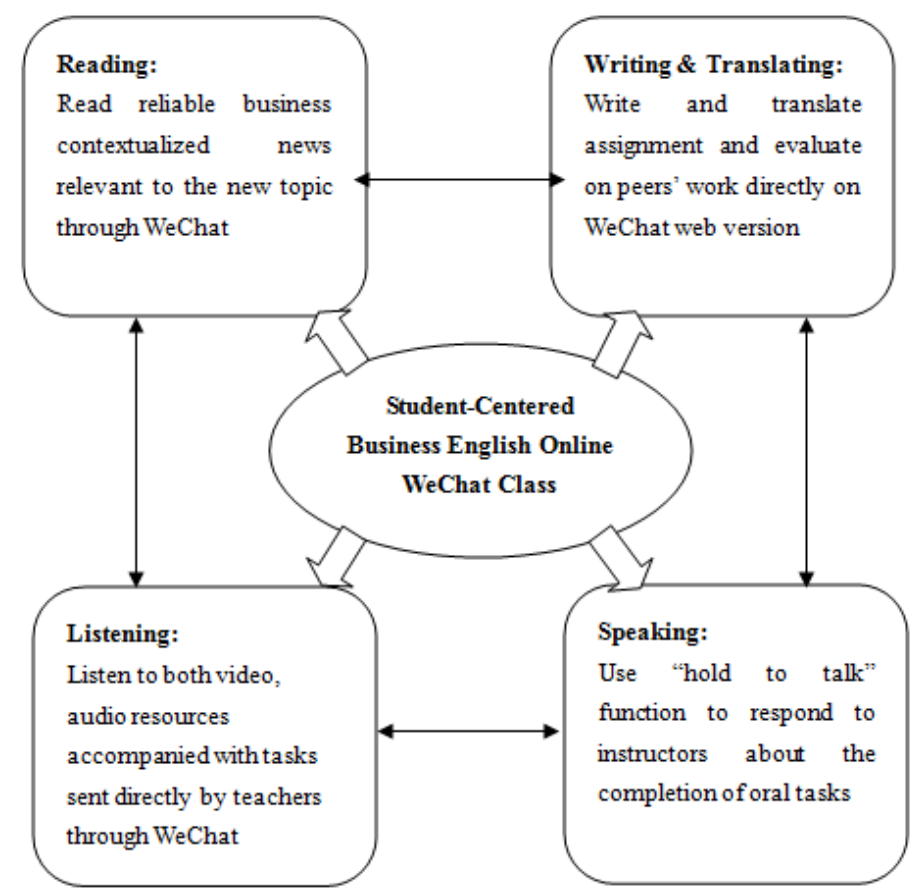

Diagram 2. Assorted language skills practiced through WeChat

Specifically, regarding reading courses, teachers can release some reliable real-time business news and recommend popular official accounts concerning business to be excellent in both pictures and literary compositions prior to class, which can certainly provoke students' curiosity to explore deeply. These types of reading materials can be seen as the supplementary and contextualized information of the topics in the class.

With regard to the listening and oral courses, a great number of appealing videos or audios can be collected by teachers online and forwarded to students together with the assigned oral and listening tasks. With the help of WeChat, students can quickly respond by sending voice messages or video recording to complete tasks and timely solve their own doubts.

Concerning writing and translating courses, peer evaluation is greatly encouraged with the intention of viewing classmates' task completion situation. Additionally, WeChat web version offers a fantastic means for students to type their translation conveniently. By means of these, students may easily find drawbacks or existing typical problems of their own tasks. Teachers can monitor the whole process and appropriately guide them to find the answer to the problem. All of these above would absolutely develop diverse business skills and cultivate language proficiency, which can better help learners to understand business content and knowledge (Kasper, 1997).

In order to identify students' mastery situation, instructors will arrange self-assessment for students to discover their understanding difficulties and check whether their mastery of knowledge meets the expected requirements. Meanwhile, students can use the "hold to talk" function to respond to instructors about the completion of tasks. Teachers can immediately grasp the learning situation of students and understand their difficulties. This 
interactive approach could deepen the relationship between instructors and learners (Haley, 2006). Besides, teachers can make comments on students' work in time and give guidance for their improvement. Song (2006) states that WeChat in-group discussion and discussion between groups to complete assignment can make students work closely with each other, which may also deepen their interpersonal communication. In addition, WeChat online study groups are a great platform for students to discuss their assignments and cultivate their team spirit.

\subsection{In-Class Teaching Stage}

The last stage "In-Class Teaching Stage" matches up with the adjunct language instruction model to put much emphasis on language competence. From the business problem solving and business team cooperation aspect, teachers can comprehensively collect some of the difficult points that certain students encountered with from WeChat. Later in the class, teachers can explain, demonstrate and solve problems in terms of learners' difficulties. The cooperation of language teachers and content teachers is desired in the In-Class Teaching Stage, which can not only help students to further strengthen the understanding of key difficulties and receive personalized guidance, but also help them to better complete the teaching objectives effectively.

What's more, classroom collaborative learning can deepen the understanding of the content. During the class, team presentation can perfectly reveal learning outcome of each learner and enhance the team coordination. Mutual assessment among each group can inspire the collision of various thoughts and facilitate the knowledge communication, so as to foster further understanding of the purpose of teaching. In class, students no longer passively follow the inflexible rules; they are motivated by the new teaching model to express their understanding of the content freely and improve their language competence when solving business-related problems.

\section{Challenges in Content Based WeChat Teaching of Business English}

It goes without saying that content based WeChat teaching of business English is an efficient and innovative teaching model and has begun to be practiced in China's business English. However, popularity has come at a price. There may be some problems occurring and form challenges for both teachers and students.

First of all, class content is based on natural, local and authentic materials, but because of the copyright problem, some of the materials may not be integral. Especially, some of instructional materials are still having grammar or language mistakes, which require teachers to spend much more time on distinguishing them and determining the authenticity of the materials. So Marani (1998) believes that teachers are facing the pedagogical challenge of mastering thorough knowledge of the subject. It is an alert for instructors to be careful when selecting materials for a content-based class as well. Besides, teachers should constantly update the knowledge reserves and continuously track global social hot spots in order to keep up with the new trend.

Secondly, WeChat platform may lead to low attendance rate. Due to this all-round application, some students suppose that they are not necessary to attend school, because all the new words and expressions, business knowledge and language points can be acquired from WeChat, which may let them neglect the importance of classroom teaching. It should be noted that students are the main body of classroom teaching. Without the essential part, class activities could not be carried out orderly. Thus, WeChat cannot substitute traditional classroom teaching, though it will be an important assistance.

Thirdly, mobile smart phone is not only applied to mobile learning, but also to leisure online activities. The popularity of smart phones gives birth to numerous phubbers who bury themselves in handling smart phones without strong self-control ability. So WeChat teaching model may not take good effect on those students who are immersed in browsing WeChat moments or chat with others for entertainment even during their study through WeChat.

Lastly, CBI Teaching Models require students to preview and learn class materials autonomously before class. If some students do not possess adequate business knowledge and experience or reasonable English level, they may not complete the assignment and they definitely cannot catch up with the classroom teaching progress, which will lead to poor teaching effect. Only by pre-learning the relevant business knowledge and topic context, can students participate fully in study activities and fulfill their study intention.

\section{Conclusion}

Content-based instruction models mainly include theme-based language instruction model, adjunct language instruction model and sheltered content Instruction model, which are consistent with the current teaching trend. Compared with the traditional teaching mode, the three CBI models do not simply focus on language skills, but mainly concentrate on integrating language teaching and business knowledge learning. Using WeChat as a 
teaching platform can successfully break the time and space constraints and let learners seize the fragmented time to study. WeChat, as a new auxiliary teaching model, can enrich the content of business English teaching and make teaching activities more flexible. The integration of the three CBI Models and WeChat Mobile Learning Method in business English teaching can form into three stages: the first is the preparation stage, at which teachers can assess students' linguistic requirements through their WeChat group chat and select adequate topics for Wechat discussion groups, aiming at enhancing the interaction among learners; the second is online autonomous learning stage, at which, students need to look through readable learning materials and finish self-assessment tasks; the last is the classroom learning stage, at which learners will collaborate to present their acquired knowledge and at the same time, teachers will pay attention to solving the difficulties students would encounter with and deliver feasible evaluation and feedback based on their work. The combination of WeChat platform and CBI models will efficiently activate students' initiative learning ability in improving their English competence while acquiring business knowledge and meanwhile urge teachers to keep up with information technology development, adapting to the new changes of educational philosophy, persistently improving professional quality and comprehensive quality and deepening business English teaching innovation. On the whole, the integration of Content-Based Instruction Models for Business English Teaching through WeChat Platform is a new trial, which would bring challenges to both teachers and students and needs constant experiment, improvement and perfection.

\section{References}

Baecher, L., Farnsworth, T., \& Ediger, A. (2014). The Challenges of Planning Language Objectives in Content-Based ESL Instruction. Language Teaching Research, 18(1), 118-136. https://doi.org/10.1177/1362168813505381

Barrow, L., Markman, L., \& Rouse, C. E. (2009). Technology's Edge: The Educational Benefits of Computer-Aided Instruction. American Economic Journal Economic Policy, 1(1), 52-74. https://doi.org/10.1257/pol.1.1.52

Bielak, J., \& Pawlak, M. (2013). Pedagogical Options in Grammar Teaching: Springer Berlin Heidelberg.

Brinton, D., Snow, M. A., \& Wesche, M. B. (2010). Content-based second language instruction. Elt Journal, $50(9), 432$.

Dai, Y. (2014). Comparing Discussion and Lecture Pedagogy When Teaching Oral Communication in Business Course. Research in Higher Education Journal, 22.

Davies, S. (2003). Content Based Instruction in EFL Contexts. Internet Tesl Journal, 2.

Dellicarpini, M., \& Alonso, O. B. (2014). Teacher Education That Works: Preparing Secondary-Level Math and Science Teachers for Success with English Language Learners through Content-Based Instruction. Global Education Review, 1.

Dupuy, B. C. (2010). Content-Based Instruction: Can it Help Ease the Transition from Beginning to Advanced Foreign Language Classes? Foreign Language Annals, 33(2), 205-223. https://doi.org/10.1111/j.1944-9720.2000.tb00913.x

Echevarria, J., \& Short, D. J. (2010). Chapter 5: Programs and Practices for Effective Sheltered Content Instruction.

Fan, L., \& Fang, R. (2002). Internet and English Language Teaching. Media in Foreign Language Instruction.

Haley, M. H. (2006). Content-Based Second Language Teaching and Learning: An Interactive Approach, 2/E.

Hung, B. P., \& Hai, T. T. (2016). Teachers' and Students' Attitudes towards the Implementation of Content-Based Instruction in Higher Education in Ho Chi Minh City. English Language Teaching, 9(5), 106. https://doi.org/10.5539/elt.v9n5p106

Kasper, L. F. (1997). The impact of content-based instructional programs on the academic progress of ESL students. English for Specific Purposes, 16(4), 309-320. https://doi.org/10.1016/S0889-4906(97)00035-5

Kiziltan, N., \& Ersanh, C. Y. (2007). The Contributions of Theme-Based CBI to Turkish Young Learners' Language Development in English. Journal of Language \& Linguistic Studies, 3(1).

Lang, F., Zhang, K., Li, P., \& Sun, G. (2016). Computer English Teaching Based on WeChat: Springer Singapore.

Li, M. (2016). Effective improvement of business English teaching through micro-class in college. Journal of Jiamusi Vocational Institute. 
Lin, W. (2017). On Interactive Teaching Model of Translation Course Based on Wechat. English Language Teaching, 10. https://doi.org/10.5539/elt.v10n3p21

Liu, L. (2016). English Teaching Model Research Based on Network MOOC. Paper presented at the International Conference on Smart City and Systems Engineering. https://doi.org/10.1109/ICSCSE.2016.0058

Long, S. S. (1997). Content-Based Instruction in Foreign Language Education: Models and Methods by Stephen K. Stryker; Betty Lou Leaver. Hispania, 82(1), 95. https://doi.org/10.2307/346085

Marani, J. S. (1998). An Overview of Content-Based Language Instruction. College Instruction, 34.

Miyazoe, T., \& Anderson, T. (2010). Learning outcomes and students' perceptions of online writing: Simultaneous implementation of a forum, blog, and wiki in an EFL blended learning setting. System, 38(2), 185-199. https://doi.org/10.1016/j.system.2010.03.006

Qian-chun, O., \& Zi-xian, G. (2016). A Study of"Micro-Course"Regarding College English Teaching. Overseas English.

Richards, J. C., \& Rodgers, T. S. (1986). Approaches and Methods in Language Teaching: A Description and Analysis. Cambridge Univ. Press.

Satilmis, Y., Yakup, D., Selim, G., \& Aybarsha, I. (2015). Teaching Concepts of Natural Sciences to Foreigners through Content-Based Instruction. The Adjunct Model. English Language Teaching, 8(3). https://doi.org/10.5539/elt.v8n3p97

Savas, P. (2012). Micro-teaching Videos in EFL Teacher Education Methodology Courses: Tools to Enhance English Proficiency and Teaching Skills Among Trainees. Procedia - Social and Behavioral Sciences, 55(5), 730-738. https://doi.org/10.1016/j.sbspro.2012.09.558

Shi, Z., \& Luo, G. (2016). Application of WeChat Teaching Platform in Interactive Translation Teaching. International Journal of Emerging Technologies in Learning, 11(9), 71. https://doi.org/10.3991/ijet.v11i09.6113

Song, B. (2006). Content-based ESL instruction: Long-term effects and outcomes. English for Specific Purposes, 25(4), 420-437. https://doi.org/10.1016/j.esp.2005.09.002

Unirow, K. I. D. (2012). CONTENT BASED INSTRUCTION IN EFL CONTEXTS. Karya Ilmiah Dosen Unirow, 1 .

Wang, J., Gao, F., Li, J., Zhang, J., Li, S., Xu, G. T., ... Lu, L. (2017). The usability of WeChat as a mobile and interactive medium in student - centered medical teaching. Biochemistry \& Molecular Biology Education. https://doi.org/10.1002/bmb.21065

Wei, Y. (2017). Application of WeChat in English Teaching. Paper presented at the Proceedings of the 2017 International Conference on Culture, Education and Financial Development of Modern Society (ICCESE 2017). https://doi.org/10.2991/iccese-17.2017.21

Wu, P. (2013). Examining Pedagogical Content Knowledge (PCK) for Business English Teaching: Concept and Model. Polyglossi: the Asia-Pacific's voice in language and language teaching, 25, 83-94.

Xu, X., Lin, Q., Zhang, Y., Zhu, R., Sharma, M., \& Zhao, Y. (2016). Influence of WeChat on sleep quality among undergraduates in Chongqing, China: a cross-sectional study. Springerplus, 5(1), 2066. https://doi.org/10.1186/s40064-016-3730-z

Yang, X., Sun, S. L., \& Lee, R. P. (2016). Micro-Innovation Strategy: The Case of WeChat. Asian Case Research Journal, 20(02), 401-427. https://doi.org/10.1142/S0218927516500152

\section{Copyrights}

Copyright for this article is retained by the author(s), with first publication rights granted to the journal.

This is an open-access article distributed under the terms and conditions of the Creative Commons Attribution license (http://creativecommons.org/licenses/by/4.0/). 